\title{
Title: Model Tests on Piled Raft Subjected to Lateral Soil Movement
}

Author 1

- Ihsan Al-abboodi, Department of Civil Engineering, University of Basrah, Iraq, currently a PhD student, School of Computing, Science and Engineering, University of Salford, Manchester, UK, Email: i.q.alabboodi@edu.salford.ac.uk. Author 2

- Toma-Sabbagh Tahsin, BSc Civil Eng, MSc/PhD Geot. Eng, CIOB, PGCAP, FHEA Lecturer in Civil Engineering, School of Computing, Science and Engineering, University of Salford, Manchester, UK. 


\begin{abstract}
Passive loadings due to lateral soil movement induced activities are highly influencing the serviceability and safety of constructions. This research aims to investigate the influence of axial loads, sand density and the depth of moving soil on the lateral behaviour of piled raft under progressively moving sand. In order to achieve this goal taking into account the complex interaction effects of piles, cap and subsoil, a laboratory apparatus and small scale models have been designed and fabricated carefully to ensure a reasonable simulation of this geotechnical problem. It is found that the above parameters play an important role in the response of piled foundations. The value of soil displacement at which the measured moment reaches its ultimate value decreases as axial loads increase. Peak displacement of the raft has been found to be a function of soil density.
\end{abstract}

\title{
Keywords
}

Laboratory tests, Lateral ground movements, Passive piles, Piled raft. 


\section{Introduction}

Piled foundations that are subjected to lateral loads at the pile head are known as 'active piles'. However, some construction activities and natural phenomena induced lateral 'hidden loadings' on piled foundations. This kind of loading is caused by lateral movement of the surrounding ground and is called passive loading, and the piles subjected to these loadings are known as 'passive piles'. Some of lateral ground movements induced activities are illustrated in Figure 1. Safety and serviceability of structures could be highly affected by passive loadings on piles. To date, experimental results on passively loaded piled raft foundations, in which the cap being in contact with the ground surface, are limited. This geotechnical problem involves complex interaction of piled raft and soil, and has not been fully understood.

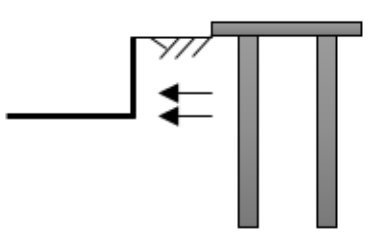

Piles adjacent to excavation

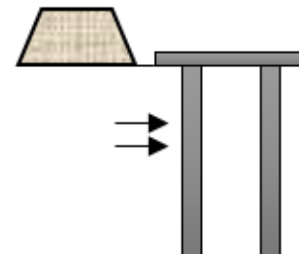

Piles adjacent to an embankment

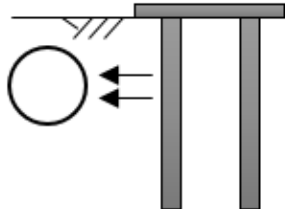

Piles adjacent to tunnelling operations

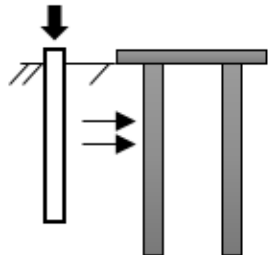

Piles adjacent to pile driving

Figure 1 Examples of passive piles.

On the simulation of soil movements, laboratory tests were carried out by either direct mobilization of soil movement or simulation of field conditions. Numerous experimental studies were made through small scale experiments and centrifuge modelling to investigate the response of single piles under lateral soil movement taking into account a wide range of influencing factors (e.g. Poulos et al. 1995; Pan 2000; White et al. 2008; Gou and Qin 2010; Suleiman 2014). Practically, piles are usually 
used in groups in which the pile-soil-cap interaction plays an important role in the behaviour of individual piles within a group. For free-standing pile group, researchers have focused on the effects of some parameters such as pile spacing, number of piles, pile diameter and head fixity condition on the lateral response of pile group (e.g. Chen et al. 1997; Leung et al. 2003; Miao et al. 2008). Ghee (2009) developed a large shear box in order to study the behaviour of pile groups exposed to axial loads and horizontal soil movement in the condition of free-standing pile group. In his experiments, holes in the cap were made $0.5 \mathrm{~mm}$ larger than pile diameter to enable the pile fitting into the pile cap holes. This gap allows the pile to rotate slightly during the test causing the pile head bending moment to be lower than that of a fully fixed pile head.

However, because the nature of free-standing pile group in which no contact pressure exists between the pile cap and the soil, researchers have neglected the contribution of pile cap in the lateral behaviour. Chen et al. (1997) stated that the reason behind using free-standing pile group in their experiments rather than piled raft was to avoid complexity in analysing the test results.

Several researchers have investigated the behaviour of passively loaded piled raft theoretically, see, for example, Bransby and Springman 1996, Martin and Chen 2005 and Zhao et al. 2008. However, experimental data for passively loaded piled raft foundations in which the soil-raft interaction is taking into account are sparse. In this context, Bransby and Springman (1997) used centrifuge model tests to study the response of piled raft embedded in two soil layers (clay and sand) adjacent to surcharge loads induced horizontal ground disturbance in clayey soil.

The main purpose of this paper is to study the influence of axial loads, sand density and the depth of moving soil on the behaviour of piled raft under lateral soil movement. 


\section{Experimental Details}

\section{The testing box}

A specially built large scale shear box has been designed and fabricated carefully to ensure a reasonable simulation of the problem as shown in Figure 2. The shear box consists of a lower $500 \mathrm{~mm}$ height stationary box made from plywood sheets and an upper section comprised of laminar plywood frames of $190 \mathrm{~mm}$ height as movable parts. The timber used to fabricate laminar frames was chosen to be smooth in order to facilitate sliding of these frames over each other. Both stationary and moving parts had $600 \mathrm{~mm}$ x $600 \mathrm{~mm}$ plan internal dimensions.

In order to ensure a straightforward lateral movement of the moving frames, the reaction frame was designed to add some weight of its parts to the upper surface of the top laminar frame. This procedure helps to prevent any probable vertical tilting of the frames while driving. Moreover, inclination of the sliding frames is also prevented in the lateral direction by adding two timber sheets along the sides of the box. Sand particles were prevented to cram between laminar frames by covering the internal surfaces of the box with a latex sheet. 


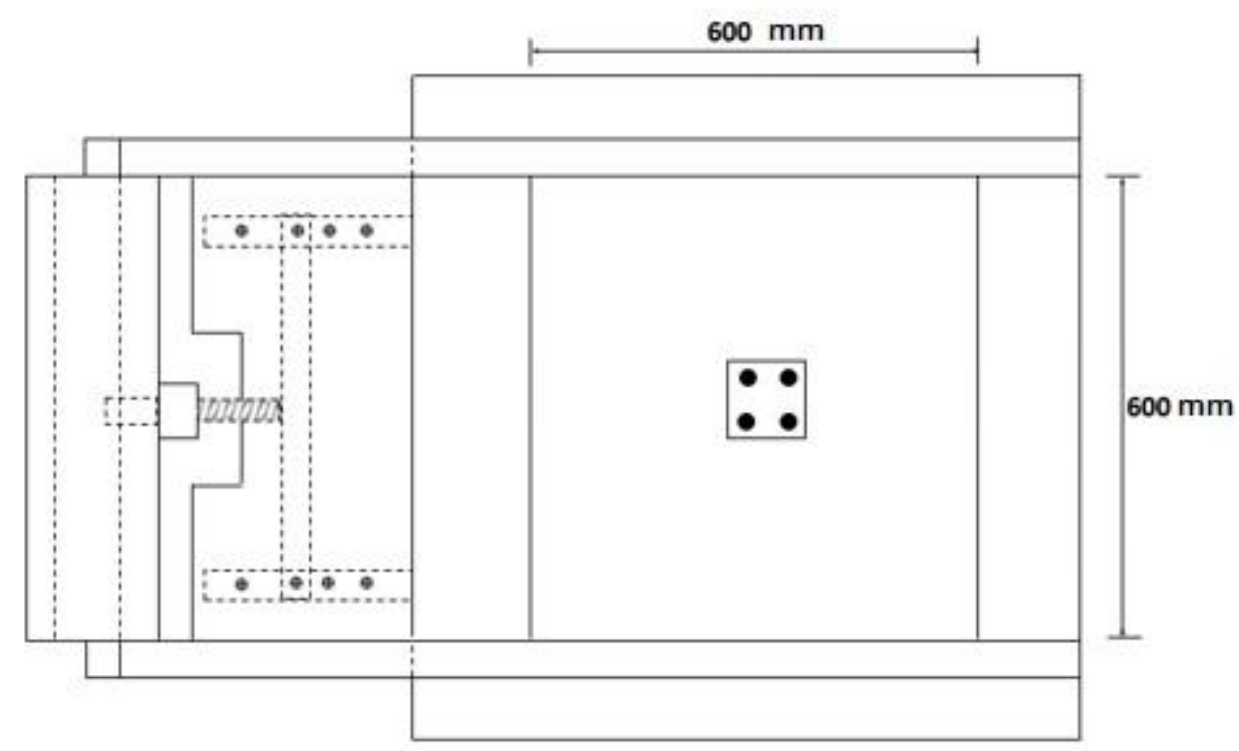

a. Plan view

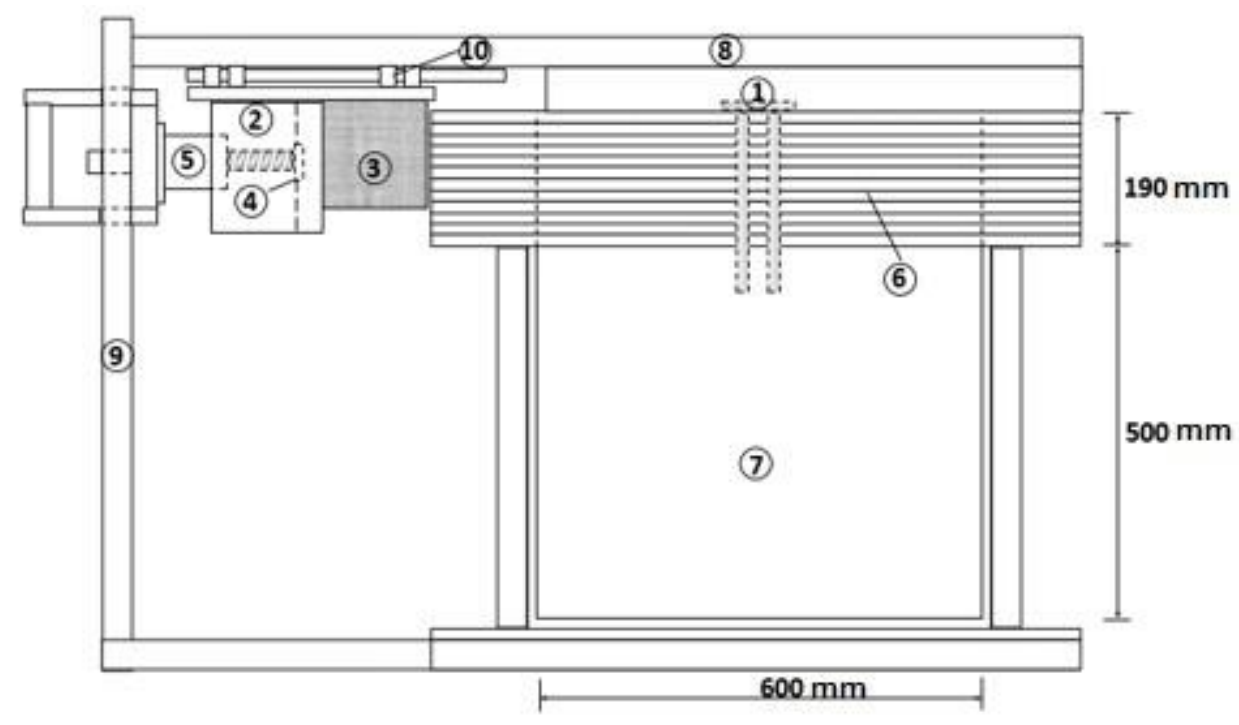

b. Elevation view

1. Pile group model 2. Loading frame 3. Loading block 4. Load cell 5. Screw jack 6. Sliding frames 7. Testing box 8. Vertical support 9. Reaction frame 10. Sliding unit.

Figure 2 Experimental apparatus showing testing box and loading frame.

\section{Reaction frame and loading system}

The reaction frame was fabricated to meet the requirements of the tests taking into account most of the possible shortcomings which might occur during the tests. The 
testing box was rested on the ground by means of three timber beams of $(90 \mathrm{~mm} \mathrm{x}$ 90mm). Two closed channels of (100 mm x $90 \mathrm{~mm})$ were placed horizontally attached to the outer timber beams and fastened to them by two end plates. Two vertical steel columns having a cross section of $(100 \mathrm{~mm} \times 100 \mathrm{~mm})$ were welded to the horizontal channels at their ends.

The lateral loading system consists of a screw jack mounted on a horizontal timber beam of ( $215 \mathrm{~mm} \times 65 \mathrm{~mm})$ cross section supported by the two vertical steel columns. The screw jack pushes a timber frame consists of an upper sheet, three side timber blocks and two loading blocks. The timber frame transfers the lateral jacking load to the loading blocks which are in a direct contact with the laminar frames causing lateral movement to these frames and to the soil inside the box. In order to induce lateral sliding to the parts of the timber loading frame as one unit, the frame was mounted from its upper timber sheet to a special sliding unit. The basic configuration of the sliding unit consists of bearing pillow block, an aluminium plate, and dual shafts. The bearing blocks was bolted to two horizontal closed channel steel beams of (100 mm x $50 \mathrm{~mm})$. Each one of these beams was bolted to the vertical steel column at its end and rested on the upper sliding frame at the other end. The sliding unit and the lateral frame are illustrated in Figure 3.

The two loading blocks have the same dimensions at each single test. Various sliding depth and shape of soil can be achieved by replacing the loading blocks with another having the desired depth and profile. 


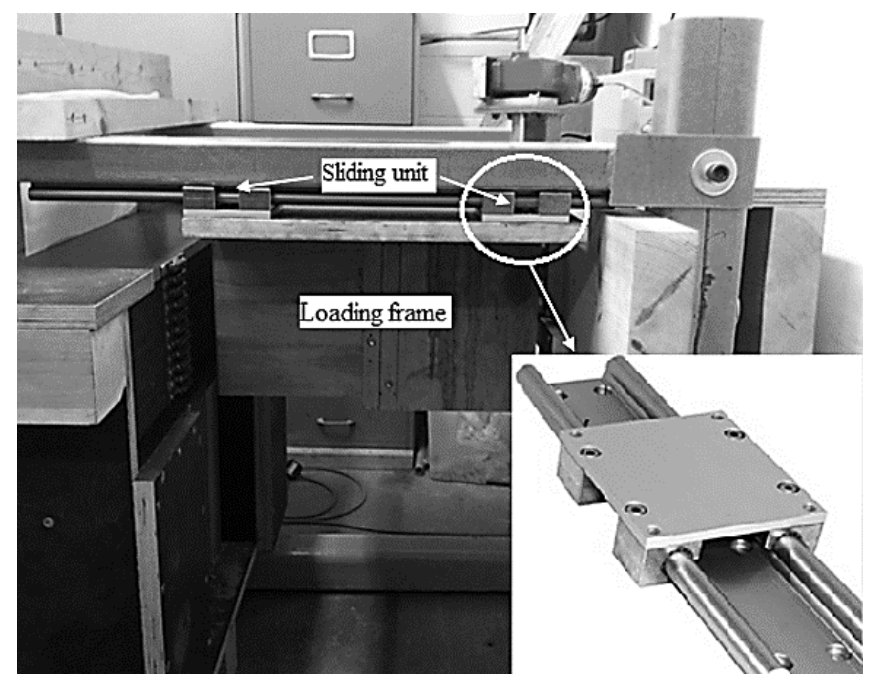

Figure 3 Loading frame and sliding unit.

\section{Model pile group and instrumentation}

The model piles used in this study were made of aluminium tubes having a length of $300 \mathrm{~mm}$, an outer diameter of $19.0 \mathrm{~mm}$ and a wall thickness of $1.0 \mathrm{~mm}$. Three times as wide as pile diameter was chosen for pile spacing $(3 d)$. To provide a frictional protection to the strain gauges during driving and testing processes, piles were covered with a special adhesive tape. Thus, the final outer diameter of piles was approximately (20) $\mathrm{mm}$. All pile surfaces were secured with the adhesive tape including the uninstrumented piles so that all model piles shared the same surface properties. Aluminium plate was used to fabricate pile cap with dimensions of $100 \mathrm{~mm}$ x $100 \mathrm{~mm}$ and a thickness of $9 \mathrm{~mm}$. Four holes were drilled through the cap thickness represent a (2x2) pile configuration. The head of each pile was completely fixed against movement and rotation to the pile cap through a screw of $(10 \mathrm{~mm})$ in diameter and $(50 \mathrm{~mm})$ in length. Details of piles and pile cap are presented in Figure 4.

In order to measure the bending moment distribution throughout the pile length, one pile at each row was instrumented from one side with seven strain gauges attached to 
its outer surface at a vertical interval of $42 \mathrm{~mm}$. Due to the change in section at pile-cap connection point and difficulty involving attachment of strain gauge directly at the pile head, the first strain gauge was positioned $6 \mathrm{~mm}$ under the pile cap. Each strain gauge has a code name starting with (SG) followed by pile name (F or B) and then a number which refers to its position (1 to 7). The letters (F or B) are used to describe the pile in terms of its location to the source of lateral loading. Hence, (F) refers to the front pile which is nearest to the source of lateral loading and influenced by the soil displacements before pile (B) or the back pile. All strain gauges used had a resistance of $120 \mathrm{ohm}$ and a gauge factor of 2.155. Quarter-bridge connection method was adopted to connect strain gauges with the data logger. Two LVDTs were used to measure the displacements of the sliding frames and the pile cap respectively. The first LVDT was placed in a direct contact to the top laminar frame, while that used for pile cap was extended by a wire mounted to a steel rod located at the centre of the cap. An inclinometer senor was used to measure the inclination of pile cap. This tilting device is suitable to measure small inclinations in a range of $\left(+/-10^{\circ}\right)$. The sensor was simply placed on the top of pile cap and fixed by means of double-sided adhesive tape.

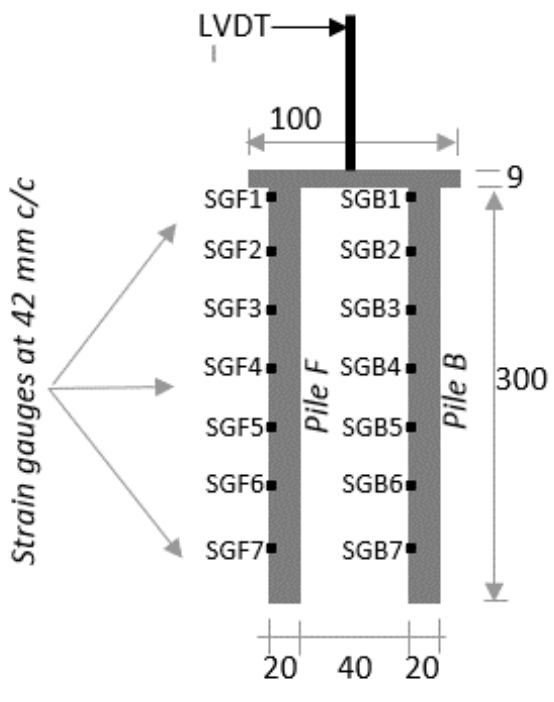

Cross section a-a
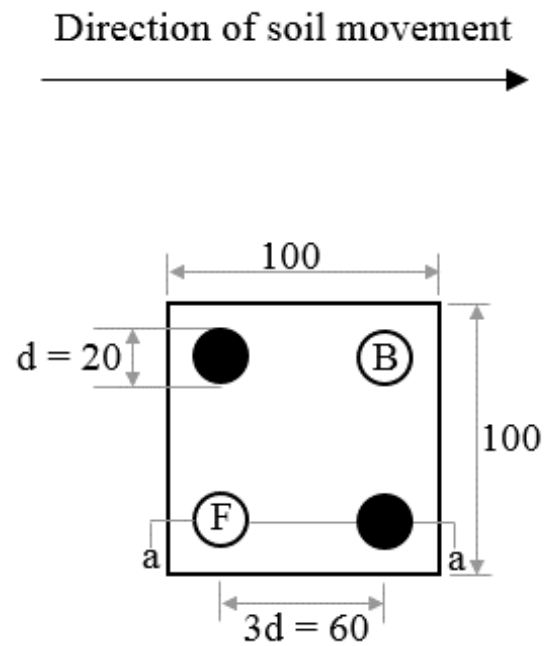

Figure 4 Details of model piles and cap, dimensions in $\mathrm{mm}$. 


\section{Driving of pile group}

In order to drive the pile group into the previously prepared sand layer, a vertical jacking system was used. The vertical jack was initially secured to the centre of the pile cap and installed until the jack reaches its maximum length. The inclination of the raft was checked carefully using a spirit level. Then, the jack arm was moved up to a certain height and a piece of hollow square steel tube with external dimensions similar to the cap dimensions was placed on the cap and installation process commenced again. During the driving process, the horizontality of the pile cap was checked and adjusted. The driving process continued until the cap reaches its final position.

\section{Sand properties and preparation}

Sand properties including classification, relative density and strength parameters tests were carried out according to British Standards BS-1377. The particle size distribution and sand parameters are illustrated in Figure 5 and Table 1 respectively. Pouring and tamping were used to achieve a reasonably predetermined constant density of the sand in the testing box. In this method, the box was divided into spaces of $50 \mathrm{~mm}$ height. These spaces were then filled with a pre-determined sand weight to achieve the required density. Subsequently, a scoop was used to pour the sand into the testing box. To achieve a loose density of sand, the scoop was lowered into the box to a height that is close to the perversely poured sand layer. When the height of fall increased, the sand becomes denser. After furnishing the sand layer, a manual compactor was also used to maintain the required height of each layer. 


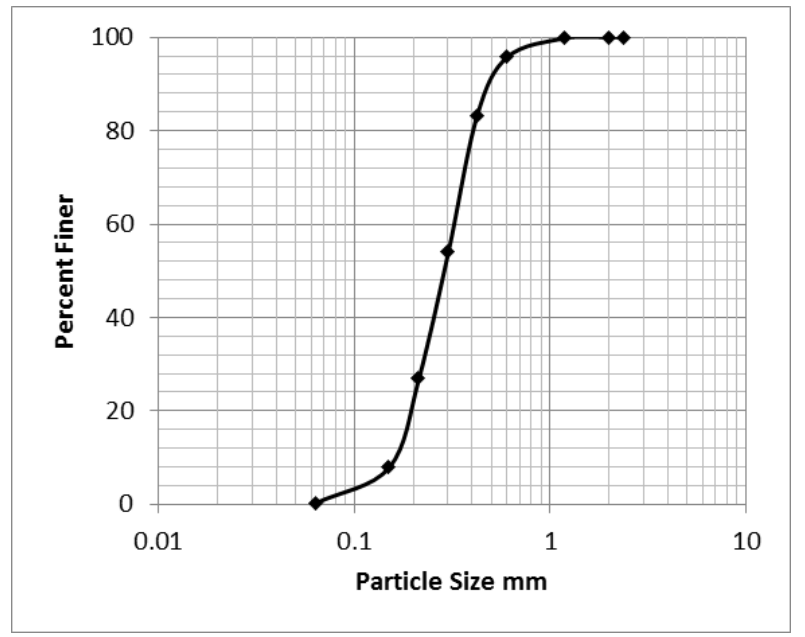

Figure 5 Particle size distribution of the sand.

Table 1 Properties of the sand used in the tests.

\begin{tabular}{|c|c|}
\hline Properity & Value \\
\hline Effective size $D_{10} \mathrm{~mm}$ & 0.15 \\
\hline$D_{30} \mathrm{~mm}$ & 0.21 \\
\hline Mean grain size $D_{50} \mathrm{~mm}$ & 0.29 \\
\hline$D_{60} \mathrm{~mm}$ & 0.31 \\
\hline Particle size range $\mathrm{mm}$ & $0.063-1.18$ \\
\hline Coefficient of uniformity $C_{u}$ & 2.06 \\
\hline Coefficient of curvature $C_{c}$ & 0.95 \\
\hline Soil classification & $\mathrm{SP}$ \\
\hline Max. dry unit weight $\mathrm{kN} / \mathrm{m}^{3}$ & 16.6 \\
\hline Min. dry unit weight $\mathrm{kN} / \mathrm{m}^{3}$ & 14.0 \\
\hline Max. void ratio & 0.9 \\
\hline Min void ratio & 0.6 \\
\hline Angle of internal friction at $\gamma=16.0 \mathrm{kN} / \mathrm{m}^{3}$ & $39^{\circ}$ \\
\hline
\end{tabular}

\section{Results}

\section{Analysis of test results}

In order to obtain the pile response in terms of shear force, soil reaction, deflection and rotation along the pile length, two methods were checked i.e. the finite difference method and polynomial curve fitting method. In the finite difference method, shear 
force and soil reaction profiles can be obtained by differentiating the bending moment profile along the pile depth to the $1^{\text {st }}$ and $2^{\text {nd }}$ order respectively. On the other hand, single and double integration of the bending moment distribution give the rotation and deflection along the pile depth respectively. The bending strains which measured by strain gauges were directly converted to bending moment values using factors obtained by calibration test. A set of bending moment distributions was then plotted against pile depth for every $5 \mathrm{~mm}$ of lateral box movement.

Shear force $\left(s_{i}\right)$ can be obtained by differentiating the bending moment $\left(m_{i}\right)$ as follows (Reese et al. 1984):

$$
S_{i}=\frac{1}{2} \frac{m_{i-1}-m_{i+1}}{\Delta z}
$$

Soil reaction (soil-pile interaction force per unit length) can be obtained (Levachev et al. 2002) using Equation 2.

$r_{i}=\frac{1}{7} \frac{2 m_{i-2}-m_{i-1}-2 m_{i}-m_{i+1}+2 m_{i+2}}{\Delta z^{2}}$

Where $m_{i}=$ bending moment at point $i, \Delta z=$ subintervals for dividing the pile length.

According to Equations (1) and (2) and in order to find the shear force values at pile head and the soil reaction at the top two locations of strain gauges, two more values of bending moments should be known (Reese and Impe 2001). For this purpose, two imaginary points located just over the pile head were assumed. To find the bending moment at those imaginary points, it was assumed that the bending moment changes linearly up to the imaginary position of the pile cap with respect to bending moment measured along the segment between the top two (actual) strain gauges. 
A number of observations can be used to supports this assumption. For example, it was noted that bending moment profile for the back pile along the upper part of the pile is, to some extent, linear. Owing to the fact that shear force is the first derivative of the bending moment, this linear change leads to conclude that the shear force profile should be constant along this pile section. To obtain this constant values of shear at pile head using shear force formula (Equation 1), bending moment should be extended in a linear variation above the pile cap (in the imaginary zone).

On the other hand, an attempt was carried out to check the accuracy of the polynomial curve fitting approach to derive the pile response in terms of shear force and soil reaction. This method involved fitting the bending moment profile to a best fit polynomial curve and then obtain the first and second derivatives of the bending moment equation to obtain the shear force and soil reaction respectively. The degree of polynomial order in which the moment curve should be fitting with is debatable. The attempt was conducted by comparing the response profiles calculated by deriving $5^{\text {th }}$ and $6^{\text {th }}$ order polynomials with those deduced by finite difference method. However, shear force and soil reaction profiles showed unrealistic increase in magnitudes at pile tip and at the point of rigid body rotation for both front and back pile rows. On the other hand, pile response using $5^{\text {th }}$ and $6^{\text {th }}$ order polynomials in the upper portion of both front and back piles is relatively agreed well with that obtained by finite difference analysis. The convergence of shear force and soil reaction values at pile head can be utilised as an additional proof to the assumption of linear variation of bending moments for those imaginary points located above the pile cap. Owing to this inconsistency in soil reaction values deduced by polynomial curve fitting method, the finite difference method is used in the current study. 


\section{Effect of axial load}

The pile cap was tested under three loading levels, i.e. $(0 \mathrm{~N}, 100 \mathrm{~N}$ and $200 \mathrm{~N})$ to examine how the change of axial loads affects the lateral response of piled raft under rectangular sand displacements. Each test has been repeated at least twice to achieve its repeatability. The maximum variation in test results observed was only $3 \%$ in load cell readings, $10 \%$ in LVDTs and tilting recordings, and $13 \%$ and $8 \%$ in strain gauge measurements in the front and back piles respectively. The depth of moving layer was kept at $135 \mathrm{~mm}$. Piles with $300 \mathrm{~mm}$ length, $20 \mathrm{~mm}$ diameter were used in the

experiments. The sand used was dense type $\left(16.0 \mathrm{kN} / \mathrm{m}^{3}\right)$. The first test with no axial load (Test PR0) was named the standard test in which its results will be part of comparison study with other testing parameters. The two other tests with $Q=100 \mathrm{~N}$ and $Q=200 \mathrm{~N}$ were denoted as PR1 and PR2 respectively.

Figure 6 illustrates the bending moment variation with lateral box displacement. For the standard test, front pile showed negative moments up to $6 \mathrm{~mm}(0.3 d$, where $d$ is the pile diameter) of box displacement. This could be due to the restraint that the pile cap provided to the piles. As soil movement continues, the pile developed positive moments along its entire depth. However, beyond $18 \mathrm{~mm}$ of soil displacement onwards, the rate of measured moments started to decrease at all strain gauge locations, and some of them (SGF1, SGF2, SGF6 and SGF7) have reached their maximum moments. It is noted that bending moment curves for the back pile row have shown gradual increase. Thereafter, strain gauges which recorded positive moment reached peak value at $7.0 \mathrm{~mm}(0.35 d)$ of box displacement, while those gauges which showed negative values recorded their constant moment at about $17.0 \mathrm{~mm}(0.85 d)$ of soil movement.

From those three test results, it is noticed that the value of box displacement at which the measured moment reaches its peak value decreases as axial loads increase. 


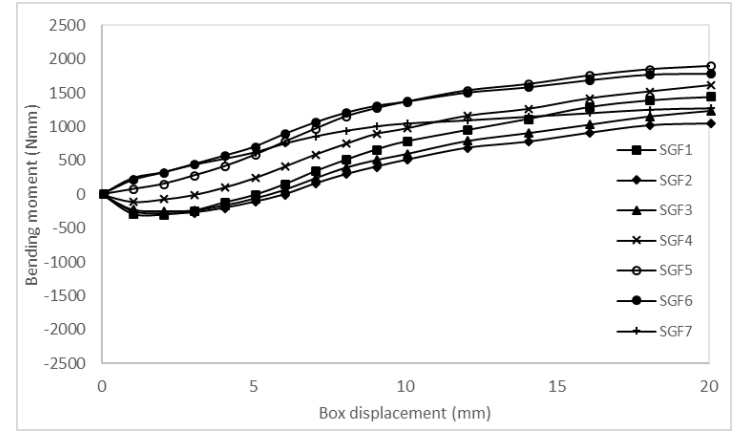

a. Test PR0, Pile-F

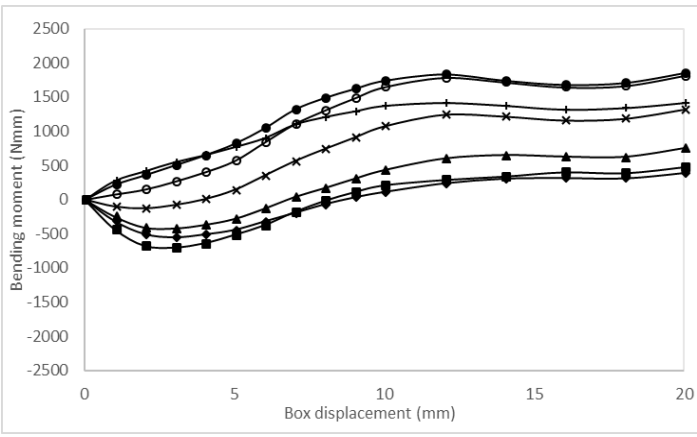

c. Test PR1, Pile-F

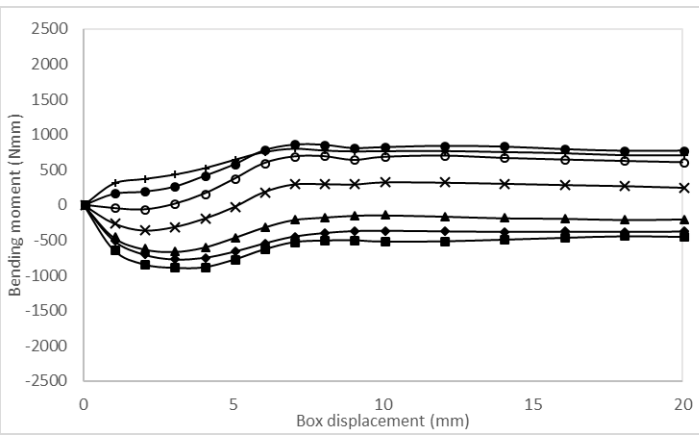

e. Test PR2, Pile-F

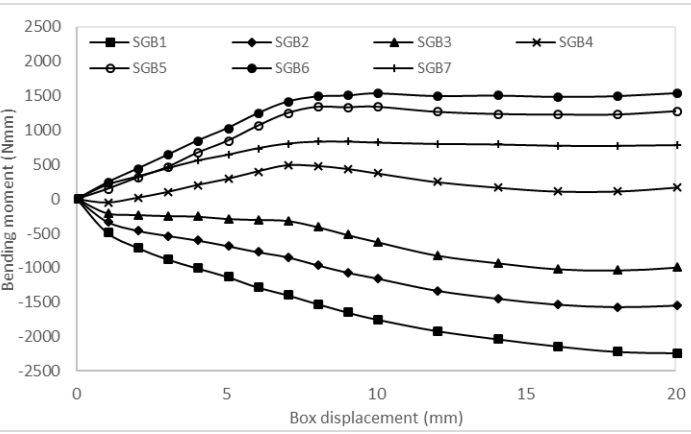

b. Test PR0, Pile-B

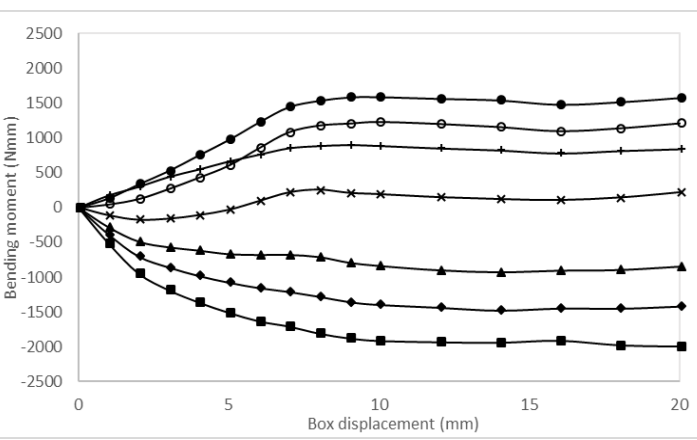

d. Test PR1, Pile-B

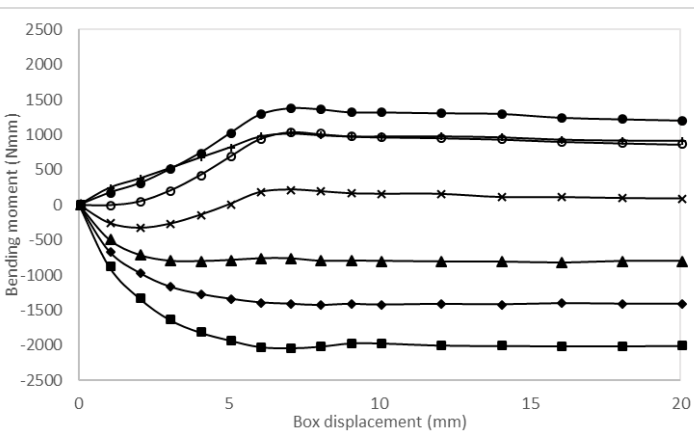

f. Test PR2, Pile-B

Figure 6 Measured moments at each strain gauge during tests (PR0, PR1 and PR2).

Figure 7 shows bending moment variation along the pile lengths at two sand displacement intervals i.e. $\Delta_{B}=5 \mathrm{~mm} 20 \mathrm{~mm}$ (where $\Delta_{B}$ is box displacement). According to this Figure, the following observations can be drawn: 
- The comparison reveals that bending moments measured at the head of the front pile were influenced significantly by the presence of axial load. A noticeable tendency to develop negative pile head moments as axial load increased was observed. This behaviour can be attributed to the additional restraint that axial load on the cap is providing. Tests with $Q=100 \mathrm{~N}$ and $200 \mathrm{~N}$ showed that bending moments at $\Delta_{B}=5 \mathrm{~mm}$ were higher than those recorded at $\Delta_{B}=20 \mathrm{~mm}$. On the other hand, a significant positive pile head moment was developed in the standard test.

- The three test results for the back piles showed that the negative pile head moment was increased with increasing the level of axial load at $\Delta_{B}=5 \mathrm{~mm}$. However, at $\Delta_{B}=20 \mathrm{~mm}$ the trend of the results was much close to that recorded in the standard test.

- At $\Delta_{B}=5 \mathrm{~mm}$, the position of zero bending moment was shifted downward to the sliding surface as axial load increased.

- Despite the negative moment measured at the moving part of Pile F, bending moment distributions at each row show similar profiles in all cases $(Q=0,100$, $200 \mathrm{~N})$.

- The positions of maximum positive and negative moments for both $\mathrm{F}$ and $\mathrm{B}$ piles did not change with the change in axial loads. Pile F shows maximum moment at depth $216 \mathrm{~mm}(0.72 L)$, whereas pile B exhibits maximum negative and positive moments at its head and $216 \mathrm{~mm}$ respectively.

- It can also be observed that back piles developed higher moments than the front pile regardless of the magnitude of axial load applied. 


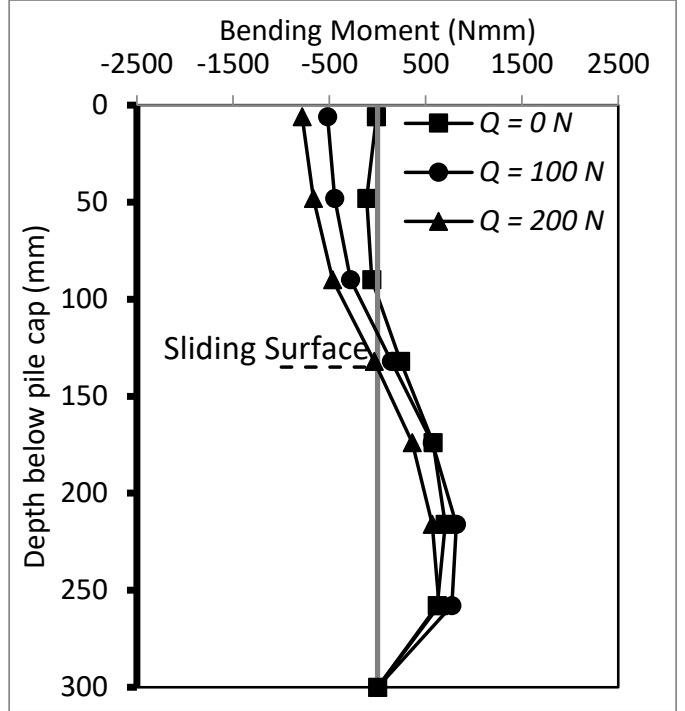

a. Front pile (at $\Delta_{B}=5 \mathrm{~mm}$ )

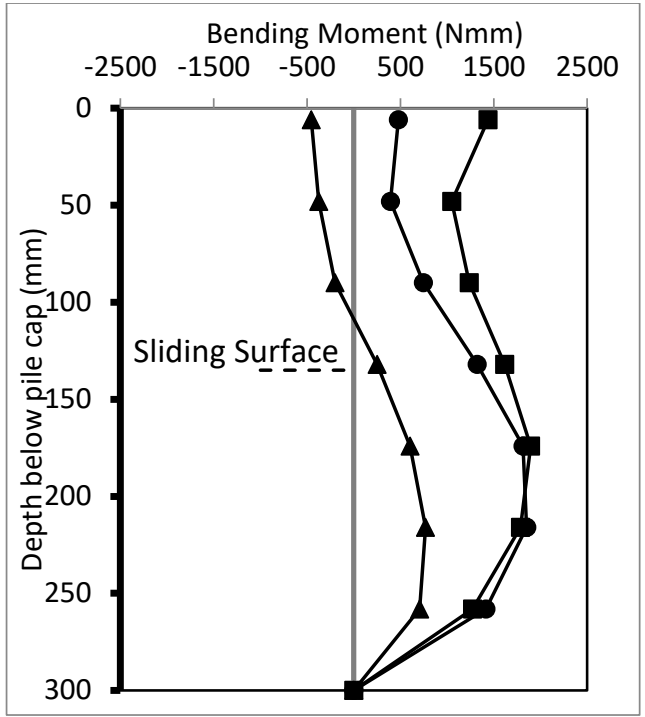

b. Front pile (at $\left.\Delta_{B}=20 \mathrm{~mm}\right)$

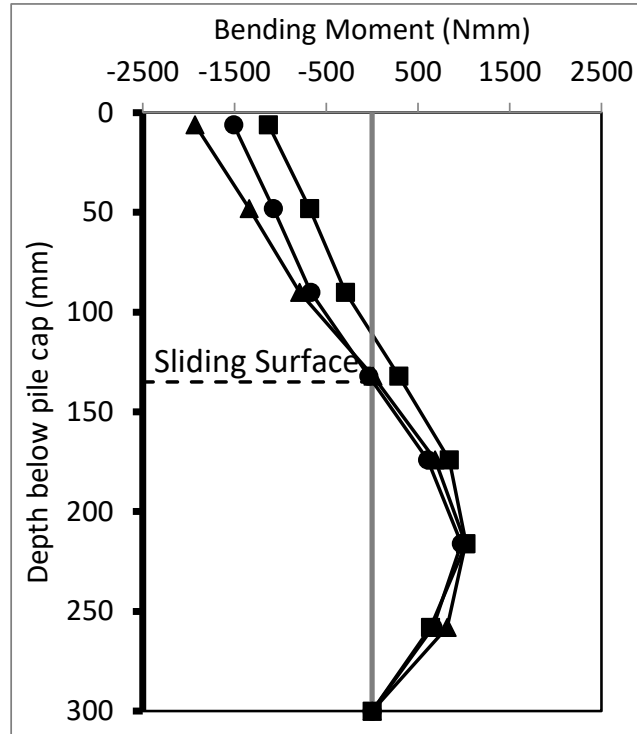

c. Back pile (at $\Delta_{B}=5 \mathrm{~mm}$ )

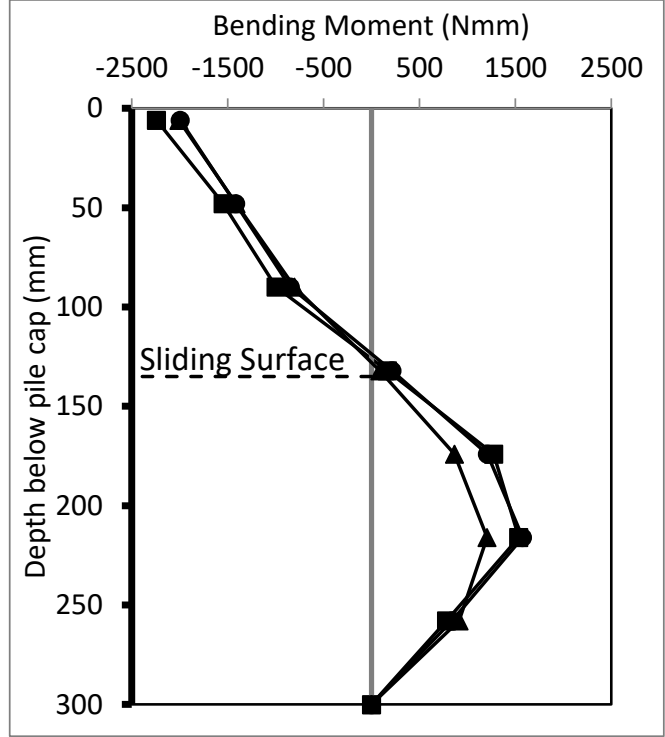

d. Back pile (at $\left.\Delta_{B}=20 \mathrm{~mm}\right)$

Figure 7 Moment profiles at different levels of axial load at $\Delta_{B}=5 \mathrm{~mm}$ and $20 \mathrm{~mm}$.

Figure 8 shows that adding axial load reduces cap deformation effectively. Two distinct zones were observed: linear increase of cap deformation with increasing box displacement and then it became constant at larger displacement values. The magnitude of horizontal sand displacement at which the cap started to achieve its constant deformation is clearly related to the level of axial load. The length of linear 
portion of the curve is inversely proportional with the intensity of axial load applied to the pile cap.

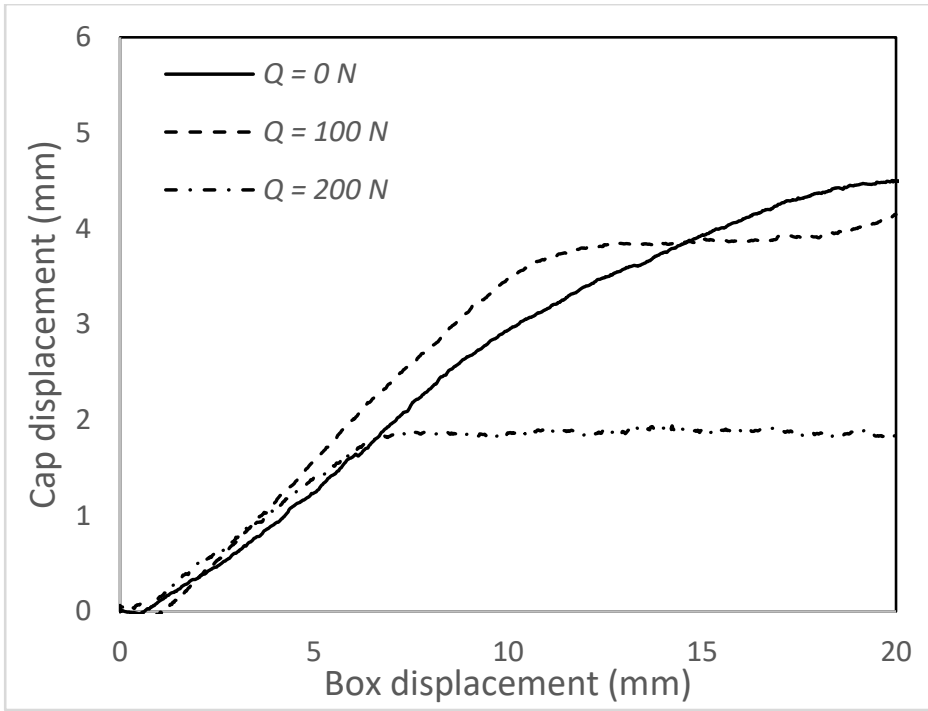

Figure 8 Cap displacement versus box displacement for different values of $Q$.

\section{Effect of sand density}

Two different densities results have been compared to investigate the influence of sand density on the lateral behaviour of passively loaded piled raft. In addition to the standard test which has been conducted with sand density of $16.0 \mathrm{kN} / \mathrm{m}^{3}$, another test was carried out with a density of $\left(14.4 \mathrm{kN} / \mathrm{m}^{3}\right)$ which represents the loose state. The comparison was presented in terms of moment and soil reaction at $\Delta_{B}=20 \mathrm{~mm}$.

Figure 9 shows that reducing the soil strength resulting in a distinct reduction in induced bending moment at both rows of piles. Although the moment curve of the front row in loose sand shows some differences compared to that measured in dense sand with regard to the position of maximum bending moment, pile head moment was recorded values of nearly threefold of those in loose sand. Back pile row exhibits less difference in the measured pile head moment in which it increased about $50 \%$ when soil density increased from $14.4 \mathrm{kN} / \mathrm{m}^{3}$ to $16.0 \mathrm{kN} / \mathrm{m}^{3}$. The reason behind the limited effect of the 
back pile compared to the front pile may be attributed to the fact that the governing factor influencing the response of back pile is the pile-cap interaction rather than the soil state. It is also shown that both curves are identical including the position of maximum and minimum bending moments.

Soil-pile interaction force per unit length measured on piles $\mathrm{F}$ and $\mathrm{B}$ indicates that its magnitude is highly dependent on the strength of soil layer. Piles embedded in dense sand were under higher soil reaction compared to those embedded in loose sand. The position of maximum passive and active soil reactions, in general, were recorded to be within the middle third of the moving and stable layers respectively. It is also noticed that no passive soil reaction was detected on the upper portion of the back pile tested in loose sand, unlike that observed in dense sand. This observation suggests that the shadowing effect of the front pile increases as soil density decreases. 

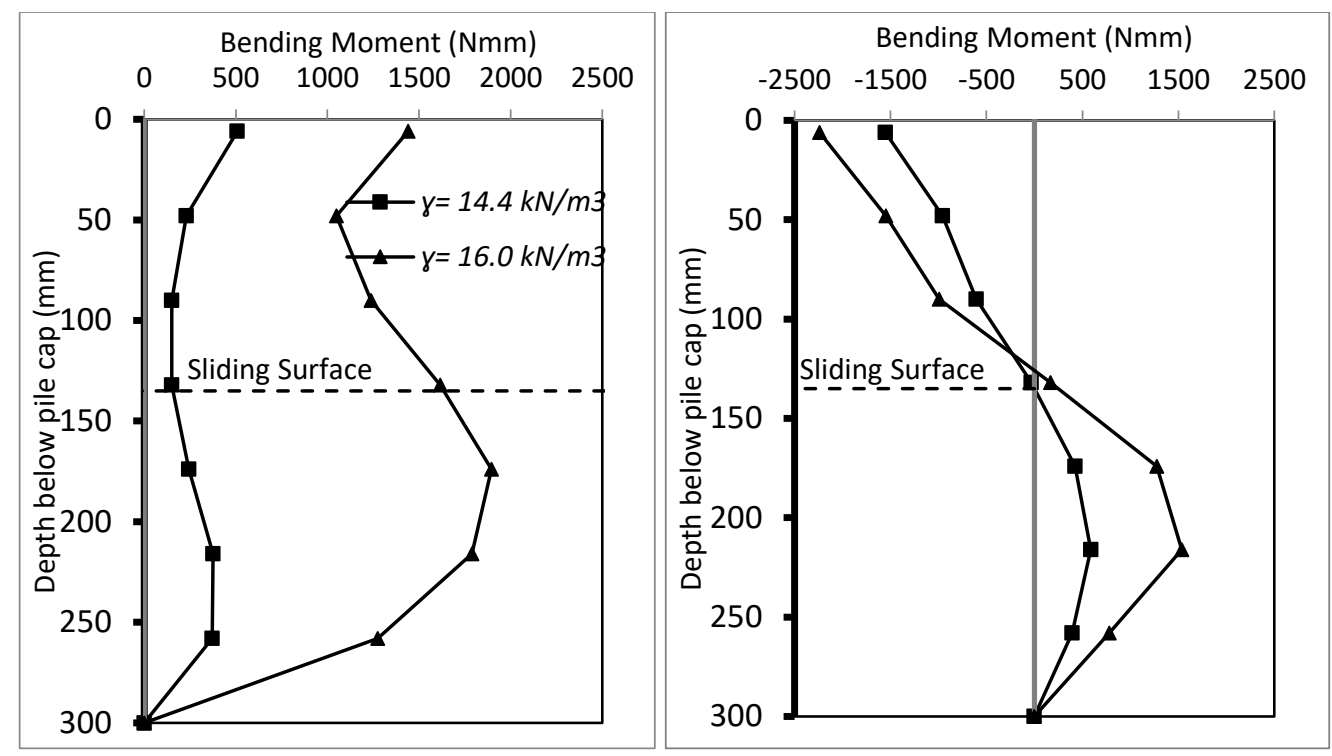

a. Bending moment of Pile F.

b. Bending moment of pile B.
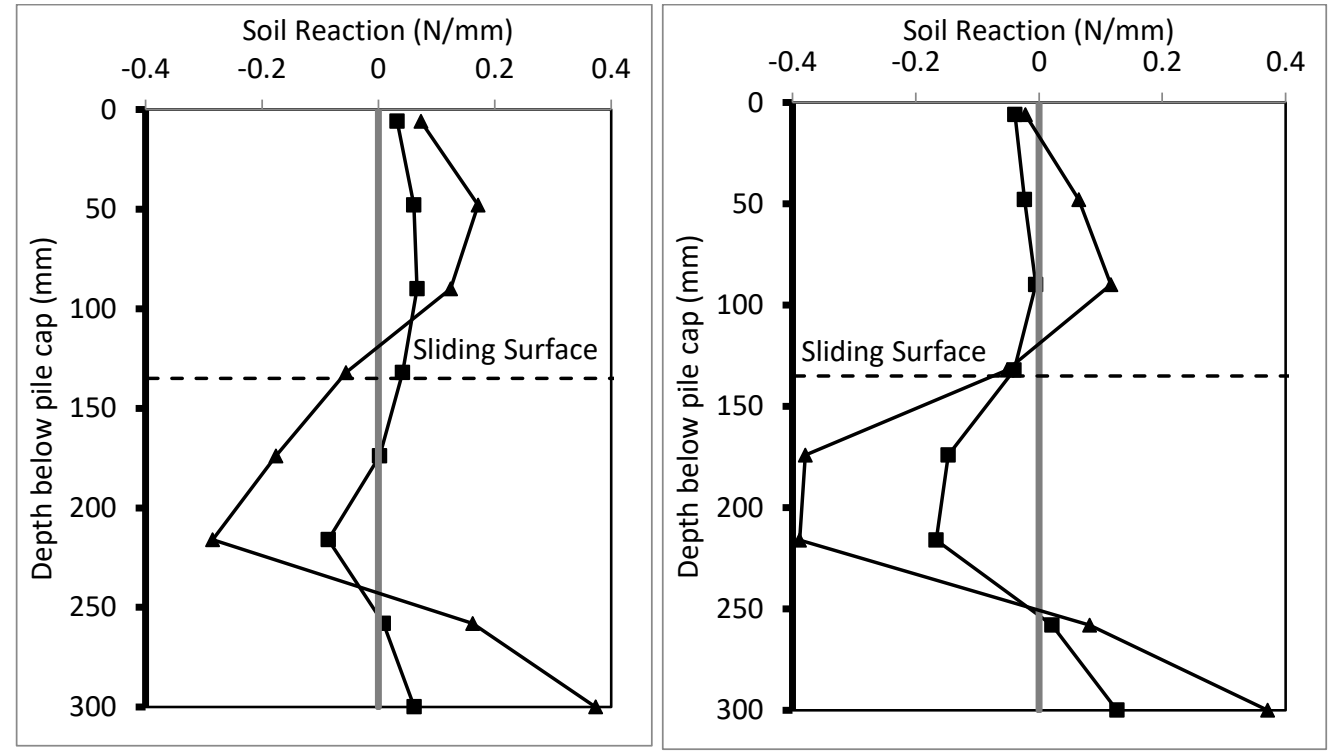

c. Soil reaction of Pile F.

d. Soil reaction of pile B.

Figure 9 Front and back pile response at two values of sand density at $\Delta_{B}=20 \mathrm{~mm}$.

Cap displacement versus box displacement (up to $25 \mathrm{~mm}$ ) relationship is presented in Figure 10. It is clear that the cap displacement is linearly increased with increasing sand displacement in the box for piled raft in loose sand, in which no peak displacement has been detected throughout the test. On the other hand, piled raft tested in dense sand 
tends to develop ultimate cap displacement at $\Delta_{B}=20 \mathrm{~mm}$ or $(1 d)$, after which the cap shows constant displacement with increasing soil movement.

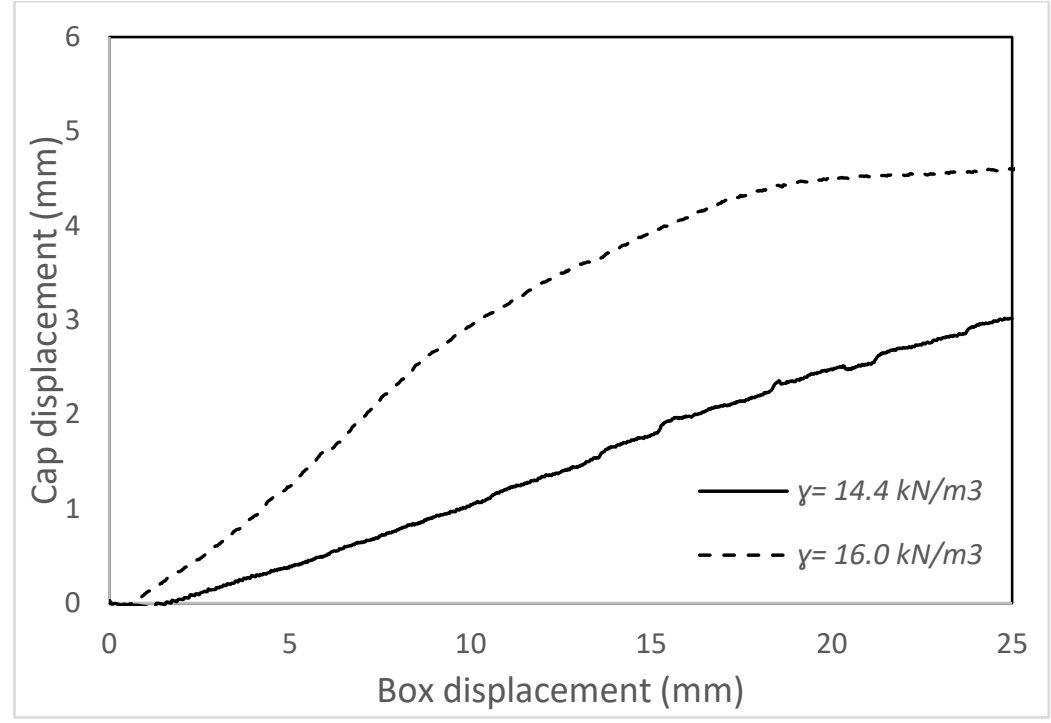

Figure 10 Cap displacement versus box displacement.

\section{Effect of moving / embedded depth ratio}

To investigate the influence of the depth of moving layer $\left(L_{m}\right)$ on the behaviour of piled raft under lateral soil movement, a test with $L_{m}=100 \mathrm{~mm}$ was conducted, so that its results is compared with the results obtained from the standard test which was carried out with $L_{m}=135 \mathrm{~mm}$. Hence, the corresponding $L_{m} / L$ ratios are 0.33 and 0.45 respectively. In the laboratory setup, the depth of moving sand can simply be changed by changing the level of soil surface in the box with no need to change the loading block. The comparison was presented in terms of moment, shear force, soil reaction and cap displacement measured at $\Delta_{B}=20 \mathrm{~mm}$.

Bending moment variation with lateral box movement recorded by two selected strain gauges (SGF6 and SGB6) located on the same level (216 mm under the pile cap) on Piles F and B respectively is illustrated in Figure 11. It can be seen that peak moment at $L_{m}=100 \mathrm{~mm}$ occurred at about $4.0 \mathrm{~mm}$ of box displacement $(0.2 d)$. On the other 
hand, the peak moment was developed at about $18.0 \mathrm{~mm}$ and $9.0 \mathrm{~mm}$ of box movement in the front and back pile respectively when $L_{m}$ increased to $135 \mathrm{~mm}$. That is to say maximum bending moment at $L_{m}=100 \mathrm{~mm}$ tends to develop at smaller values of sand displacements compared to that developed when $L_{m}=135 \mathrm{~mm}$ for both piles.

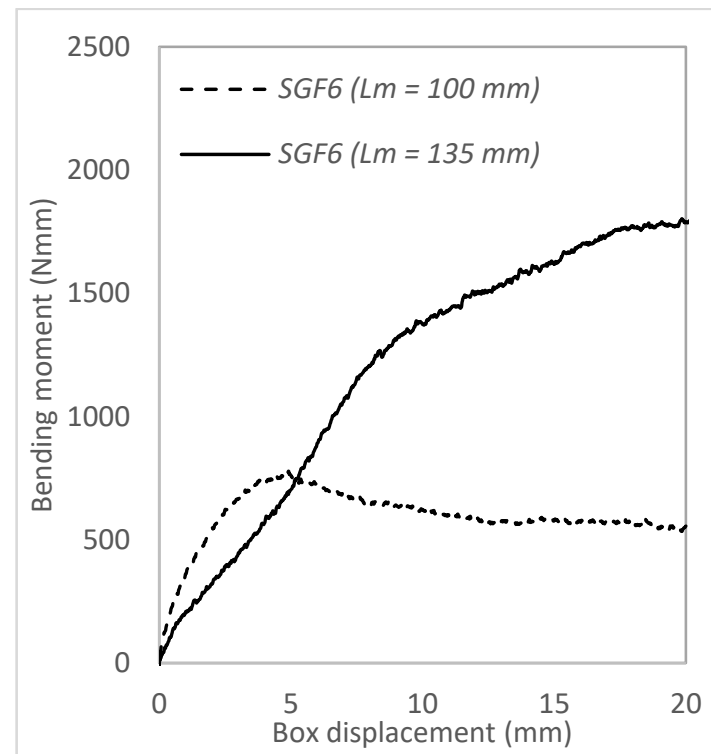

a. Pile F

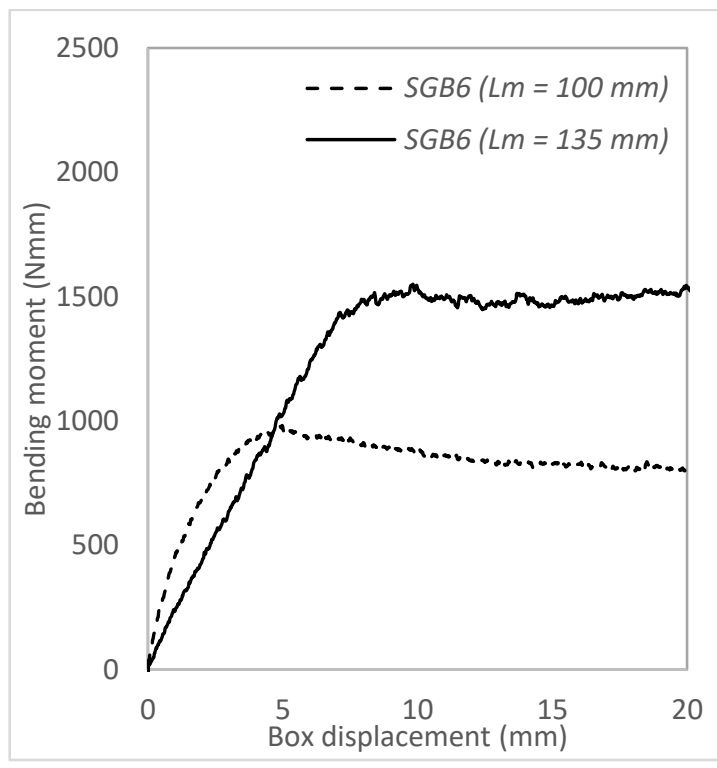

b. Pile B

Figure 11 Bending moment variation with box displacement.

Based on measured data at $\Delta_{B}=20 \mathrm{~mm}$ portrayed in Figure 12, it can be seen that bending moment increased as the depth of moving soil increased. The maximum bending values in the front pile occurred at a depth ranging from $174 \mathrm{~mm}$ and $216 \mathrm{~mm}$ below the pile cap for both tests. Therefore, it is evident that changing the depth of moving soil does not affect the position of maximum moment in the front pile. On the other hand, Figure 12 (b) depicts that maximum moment developed at the back pile showed different locations with changing $L_{m}$ values. However, both curves shared the same tendency to locate the position of zero moment close to the corresponding sliding surface location. The increase in induced maximum moments measured at those 
positions in piles $\mathrm{F}$ and B resulting from increasing $L_{m}$ from $100 \mathrm{~mm}$ to $135 \mathrm{~mm}$ were about $280 \%$ and $180 \%$ respectively.

Maximum shear force in the front pile occurred at a depth closed to the pile tip (258 mm under the soil surface), while it was in the vicinity of the sliding surface in the back pile row for both tests.

Figure 12 (e and $\mathrm{f}$ ) reveals that the shape of soil reaction profile is independent of the depth of moving layer, but the values are highly related to that depth. A noticeable increase in soil reaction was observed as $L_{m}$ increased from $100 \mathrm{~mm}$ to $135 \mathrm{~mm}$. 


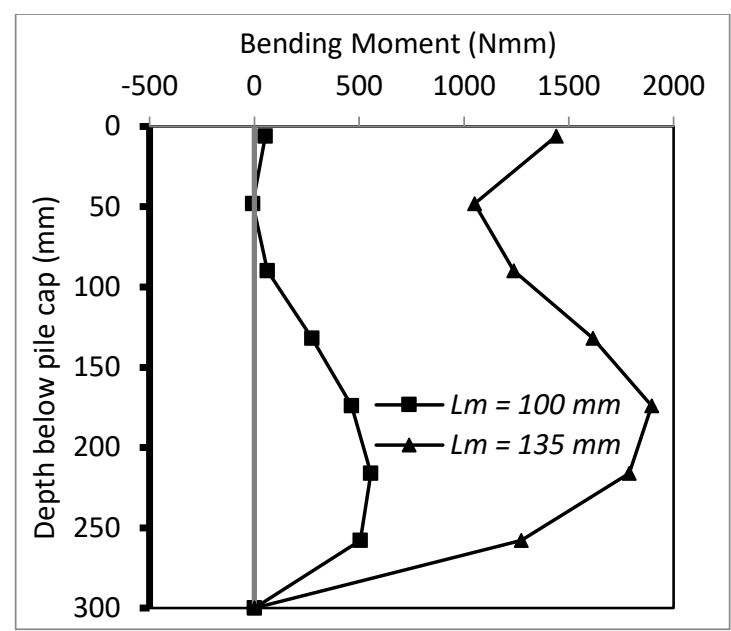

a. Bending moment of Pile F

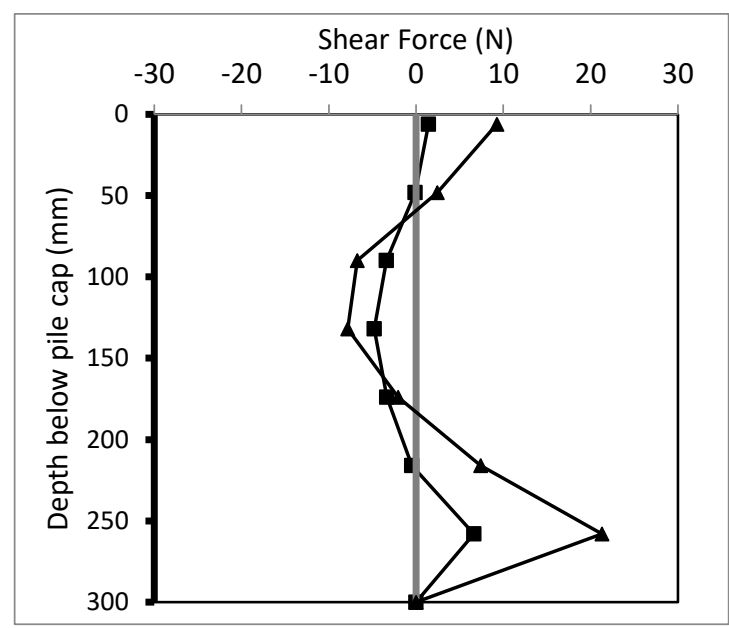

c. Shear force of Pile F

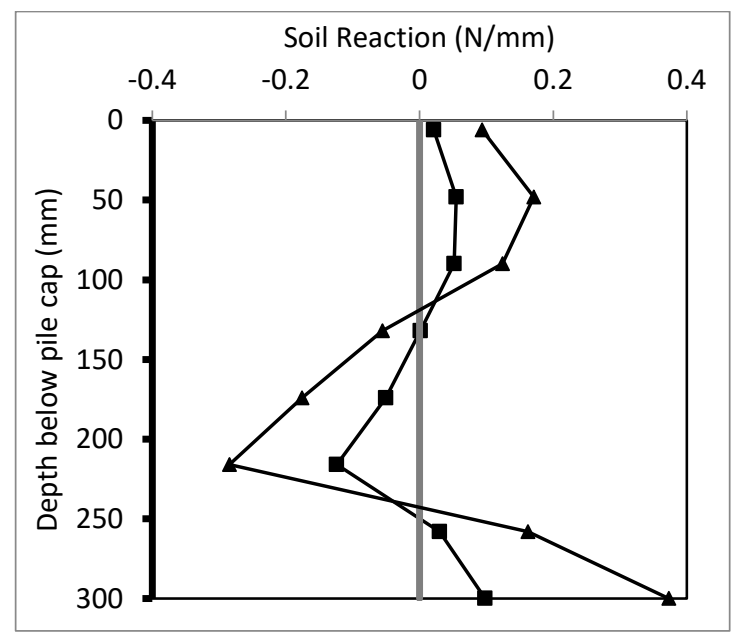

e. Soil reaction of Pile F.

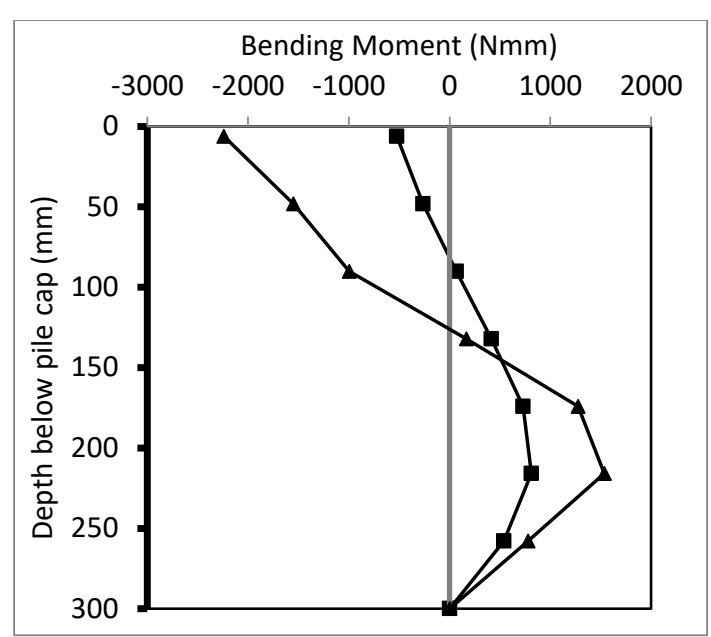

b. Bending moment of Pile B.

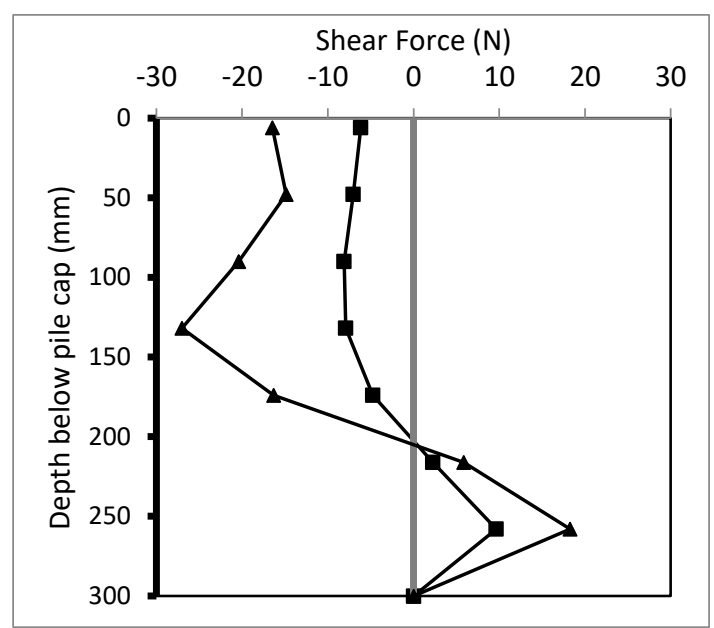

d. Shear force of Pile B.

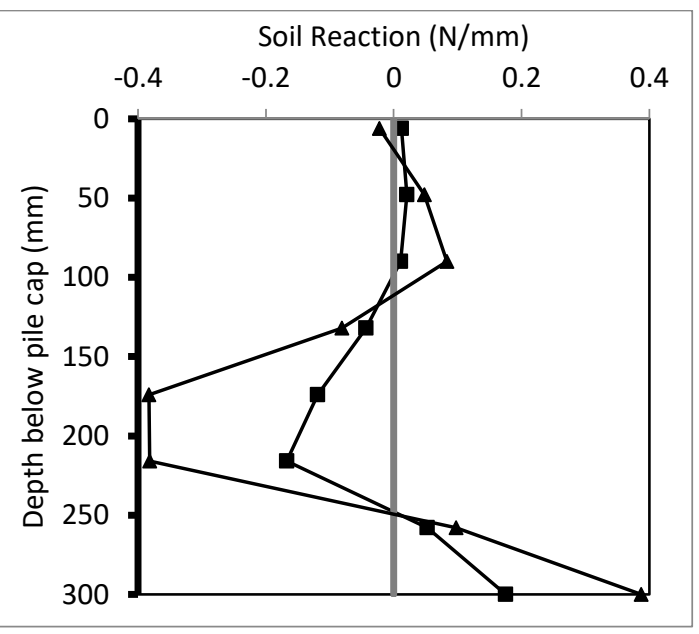

f. Soil reaction of pile B.

Figure 12 Front and back pile response at $L_{m}=100 \mathrm{~mm}$ and $135 \mathrm{~mm}$ at $\Delta_{B}=20 \mathrm{~mm}$. 
The relationship of the soil-pile contact force per unit length versus relative soil-pile displacement at depth $216 \mathrm{~mm}$ under the soil surface for both front and back piles is shown in Figure 13. Test results revealed that load-displacement curves are nonlinear. For test with $L_{m}=100 \mathrm{~mm}$, the ultimate soil force was recorded at $\Delta_{B}=5 \mathrm{~mm}(0.25 d)$ for both piles. By increasing the moving depth to $135 \mathrm{~mm}$, the magnitudes of ultimate soil force and the corresponding relative displacements were increased. Soil-pile interaction force per unit length showed maximum values of $0.28 \mathrm{~N} / \mathrm{mm}$ and 0.38 $\mathrm{N} / \mathrm{mm}$ for the front and back piles respectively, and both values were recorded at $\Delta_{B}=$ $19 \mathrm{~mm}(0.95 d)$. Furthermore, it is noted that the shape of load-displacement curve was changed from strain-softening to strain-hardening type as depth of moving layer increased.

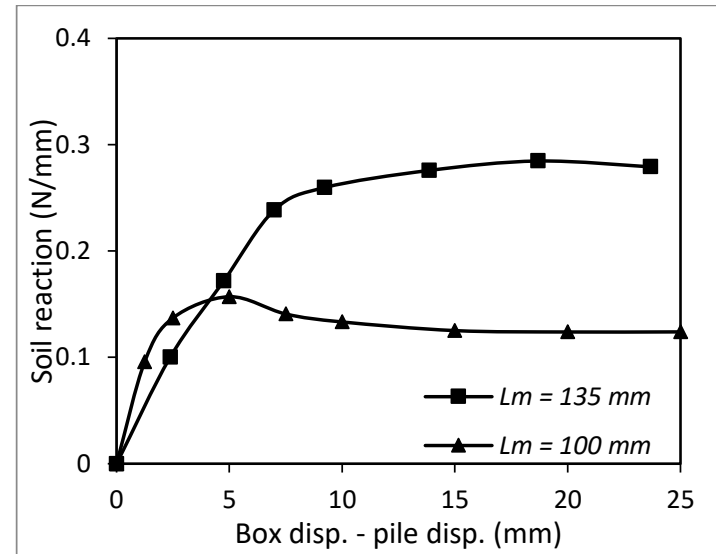

a. Pile F

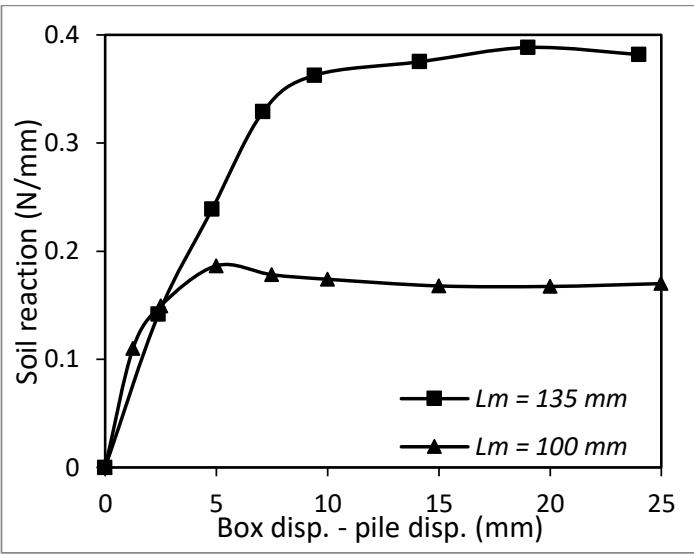

b. Pile B.

Figure 13 Soil-pile interaction force versus relative displacement at depth $216 \mathrm{~mm}$ under soil surface.

\section{Conclusions}

This paper defines the results of experimental tests carried on piled raft foundations subjected to uniform soil movement. These tests were performed with three levels of 
axial loads $(0 \mathrm{~N}, 100 \mathrm{~N}, 200 \mathrm{~N})$, two soil densities $\left(14.4 \mathrm{kN} / \mathrm{m}^{3}\right.$ and $\left.16.0 \mathrm{kN} / \mathrm{m}^{3}\right)$ and two moving/embedded depth ratios $\left(L_{m} / L_{=} 0.33\right.$ and 0.45$)$

In addition to the lateral displacement of the pile cap, the response was presented in terms of bending moment, shear force, and soil reaction measured along pile depth.

Based on the experimental results, the following conclusions can be drawn:

1. Test results generally indicate that the behaviour of front pile row has significantly affected by the axial loads. A noticeable shifting of pile head moment from positive to negative values was observed as axial load increased. On the other hand, the difference in bending moments is less pronounced for higher values of axial load in the back pile row.

2. From the first three test results, it is noticed that the value of soil displacement, at which the measured moment reaches its ultimate value, decreases as axial loads increase.

3. The magnitude of lateral soil movement, at which the pile cap achieved its constant deformation, is clearly related to the level of axial load.

4. Soil density plays an important role in the behavioural mode of passive piles. Soil reaction measured along pile length indicates that its magnitude is a function of soil strength. Piles embedded in dense sand were under higher soil reaction compared to those in loose sand.

5. It is noted that the shape of $p-y$ curve changes from strain-softening to strainhardening type as depth of moving layer increases. 


\section{References}

Bransby, M. F., and Springman, S. M. 1996. 3-D finite element modelling of pile groups adjacent to surcharge loads. Computers and Geotechnics, 19, (4), 301-324.

Bransby, M. F., and Springman, S. M. 1997. Centrifuge modelling of pile groups adjacent to surcharge loads, Soils and Foundations, 37, (2), 39-49.

Chen, L. T., Poulos, H. G., and Hull, T. S. 1997. Model tests on pile groups subjected to lateral soil movement. Soils and Foundations, 37, (1), 1-12.

Ghee, H. 2009. The behaviour of axially loaded piles subjected to lateral soil movements. Doctoral thesis. Griffith University.

Guo, W., and Qin, H. Y. 2010. Thrust and bending moment of rigid piles subjected to moving soil. Canadian Geotechnical Journal, 47, (2), 180-196.

Leung, C. F., Lim, J. K., Shen, R. F. and Chow, Y. K. 2003. Behavior of pile groups subject to excavation-induced soil movement. Journal of Geotechnical and Geoenvironmental engineering, ASCE, 129, (1), 58-65.

Levachev, S. N., Fedorovsky, V. G., Kurillo, S. V. and Kolsenikov, Yu. M. 2002. Piles in hydrotechnical engineering. A. A. Balkma.

Martin, G., and Chen, C. 2005. Response of piles due to lateral slope movement. Computers and Structures, 83, (8-9), 588-598.

Miao, L. F., Goh, A. T. C., Wong, K. S. and The, C. I. 2008. Ultimate soil pressure for pile groups in soft clay subjected to lateral soil movements. Deep Foundation Institute Journal 2, (1), 42-51. 
Pan, J.L., Goh, A. T. C., Wong, K. S. and The, C. I. 2000. Model tests on single piles in soft clay. Canadian Geotechnical Journal, 37, (4), 890-897.

Poulos, H. G., Chen, L. T., and Hull, T. S. 1995. Model tests on single piles subjected to lateral soil movement. Soils and Foundation, 35, (4), 85-92.

Reese, L. C., Cooley, L. A. and Radhakrishnan, N. 1984. Laterally loaded piles and computer program COM624G. U.S. Army Engineer Division, Lower Mississippi Valley, Vicksburg, MS, Technical Report K-84-2.

Reese, L. C. and Van Impe, W. F. 2001. Single piles and pile groups under lateral loading. Rotterdam, A. A. Balkema.

Suleiman, M. T., Ni, L., Helm, J. D., and Raich, A. 2014. Soil-pile interaction for a small diameter pile embedded in granular soil subjected to passive loading. Journal of Geotechnical and Geoenvironmental Engineering, ASCE, 140, (5), 04014002.

White, D. J., Thompson, M. J., Suleiman, M. T and Schaefer, V. R. 2008. Behavior of slender piles subject to free-field lateral soil movement. Journal of Geotechnical and Geoenvironmental Engineering, ASCE, 134, (4), 428-436.

Zhao, M., Liu, D., Zhang, L., and Jiang, C. 2008. 3D finite element analysis on pilesoil interaction of passive pile group. Journal of Central South University of Technology, 15, 75-80. 


\section{Figure captions}

Figure 1 Examples of passive piles.

Figure 2 Experimental apparatus showing testing box and loading frame.

Figure 3 Loading frame and sliding unit.

Figure 4 Details of model piles and cap.

Figure 5 Particle size distribution of the sand.

Figure 6 Measured moments at each strain gauge during tests (PR0, PR1 and PR2).

Figure 7 Moment profiles at different levels of axial load at $\Delta_{B}=5 \mathrm{~mm}$ and $20 \mathrm{~mm}$.

Figure 8 Cap displacement versus box displacement for different values of $Q$.

Figure 9 Front and back pile response at two values of sand density at $\Delta_{B}=20 \mathrm{~mm}$.

Figure 10 Cap displacement versus box displacement.

Figure 11 Bending moment variation with box displacement.

Figure 12 Front and back pile response at $L_{m}=100 \mathrm{~mm}$ and $135 \mathrm{~mm}$ at $\Delta_{B}=20 \mathrm{~mm}$.

Figure 13 Soil-pile interaction force versus relative displacement at depth $216 \mathrm{~mm}$ under soil surface. 